\title{
Prevalence of eating disorders amongst dancers: A systemic review and meta-analysis.
}

\author{
Jon Arcelus, ${ }^{1,2}$, Gemma L. Witcomb ${ }^{1,2}$, and Alex Mitchell ${ }^{3}$ \\ ${ }^{1}$ Loughborough University Centre for Research into Eating Disorders (LUCRED), Loughborough \\ University, Loughborough, Leicestershire, LE11 3TU, UK. Tel.: +44 (0)1509 223032. Email: \\ J.Arcelus@lboro.ac.uk \\ ${ }^{2}$ Eating Disorders Service, Leicester Partnership Trust, Bennion Centre, Leicester Glenfield Hospital, \\ Leicester, LE3 9DZ, UK. \\ ${ }^{3}$ Department of Psycho-oncology, Leicester Partnership Trust, Leicester. LE5 4PW, UK. Honorary \\ Senior Lecturer in Psycho-oncology, Department of Cancer and Molecular Medicine, Leicester Royal \\ Infirmary, University of Leicester, Leicester, LE1 5WW, UK.
}

Corresponding author: Professor Jon Arcelus, Eating Disorders Service, Leicester Partnership Trust, Bennion Centre, Leicester Glenfield Hospital, Leicester, LE3 9DZ, UK. Tel.: +44 (0)116 225 2557. Email: J.Arcelus@lboro.ac.uk 


\begin{abstract}
Eating disorders in dancers are thought to be common, but the exact rates remain to be clarified. The aim of this study is to systematically compile and analyse the rates of eating disorders in dancers. A literature search, appraisal and meta-analysis were conducted. Thirty-three relevant studies were published between 1966 and 2013 with sufficient data for extraction. Primary data were extracted as raw numbers or confidence intervals. Risk ratios and 95\% confidence intervals were calculated for controlled studies. The overall prevalence of eating disorders was $12.0 \%$ (16.4\% for ballet dancers), $2.0 \%$ (4\% for ballet dancers) for anorexia, 4.4\% (2\% for ballet dancers) for bulimia, and 9.5\% (14.9\% for ballet dancers) for EDNOS. The dancer group had higher mean scores on the EAT-26 and the EDI subscales. Dancers had a higher risk of suffering from eating disorders in general, anorexia nervosa, and EDNOS, but no higher risk of suffering from bulimia nervosa. The study concluded that as dancers had a three times higher risk of suffering from eating disorders, particularly anorexia nervosa and EDNOS, specifically designed services for this population should be considered.
\end{abstract}

KEY WORDS: Eating disorders, Anorexia, Bulimia, EDNOS, Review, Meta-analysis, Dance, Ballet, Epidemiology. 


\section{Introduction}

The lifetime prevalence for anorexia nervosa in women has been estimated to be between 0.3 to 1 per cent, with a greater number suffering from bulimia nervosa (Hoek \& Van Hoeken 2003; Preti et al., 2009). However this prevalence appears to be much higher for specific groups of society, such as models (Smethurst, Wales, \& Arcelus, 2010), athletes (Sundgot-Borgen \& Torstveit, 2004) and dancers (Herbrich, Pfeiffer, Lehmkuhl, \& Schneider, 2011; Ringham et al., 2006). Research investigating the aetiology of eating disorders has identified a strong correlation between these disorders and specific personality factors, such a low self-esteem (Arcelus, Haslam, Farrow, \& Meyer, 2013), perfectionism (Penniment \& Egan, 2012; Ringham et al., 2006), and high self-standards (Gunnard, et al., 2012). The high levels of perfectionism (Nordin-Bates, Cummings, Always \& Sharp, 2011; Zoletić \& Durakovic-Belko, 2009) and low self-esteem (Benn \& Walter, 2011) found among dancers may explain why they appear to be more prevalent among this group of people. However the findings in this area are somewhat mixed and inconsistent. While some authors have found that up to $83 \%$ of dancers report some form of lifetime eating pathology (Ringham et al., 2006), others have not found a higher number of eating disorders among dancers when compared to healthy controls (Toro, Guerrero, Sentis, Castro, \& Puertolas, 2009). The disparity of the results may be explained by the differences in the populations involved (e.g., students vs professionals), the different type of dancers studied (e.g., ballet vs general), or the different tools used to make a diagnosis.

In order to investigate the rates of eating disorders among dancers, the primary aim of this study was to systematically compile and analyse the current literature examining the rates of eating disorders in the dance population, taking into consideration the great methodological variation, the type of dancers studied and the change in diagnosis over the years.

\section{Methods}




\section{Search strategy}

A systematic literature search, appraisal and meta-analysis was conducted. The following abstract databases were searched to July 2013: Medline/Pubmed, PsycINFO and Embase. Four full-text collections were searched; Science Direct, Ingenta Select, Ovid Full text, and Wiley-Blackwell Interscience. A broad range of subject headings were used to identify the relevant disorders and diagnoses. For each database search, combinations of the following eight search components were used; Eating Disorders, Eating Problems, Anorexia Nervosa, Bulimia Nervosa, Eating Disorders Not Otherwise Specified (EDNOS), Dance, Dancers, and Ballet. Two investigators selected the studies, extracted the data independently, cross-checked them and resolved disagreements. Studies that included 10 or more participants at the time of analysis were included. Those with less than 10 were considered selected case-series not suitable for ascertainment of prevalence. Reference lists of relevant articles were screened for further potential studies and citation searches were conducted. For all the included studies the following information was recorded: author, year of publication, country, response rates, number of individuals involved in the study, gender, type of dance, setting (whether the population studied were students (from elite or non-elite schools), amateurs or professionals), tools used, diagnosed life time prevalence, point prevalence rate of eating disorders, anorexia nervosa, bulimia nervosa, and eating disorders not otherwise specified (EDNOS). Information from the results of questionnaires used to measure eating psychopathology was also recorded which allowed for determination of caseness as per the Eating Attitude Test (EAT; Garner, Olmsted, Bohr, \& Garfinkel, 1982). Mean scores for the Eating Attitude Test (EAT-40 and EAT-26), Eating Disorders Inventory (EDI; Garner, Olmstead, \& Polivy, 1983), subscales of the EDI (Drive for thinness [DT], Bulimia $[B]$ and Body dissatisfaction [BD]), and Eating Disorders Questionnaire (EDE-Q; Fairburn \& Beglin, 1994) were selected. Information was also recorded from controls, plus a description of the type of controls used (e.g., non-dancers, athletes). The results are reported for; 1) all dancers, and 2) ballet dancers specifically (as a big proportion of studies exclusively selected this type of dancer). See Table 1 for further details. 


\section{Procedure and statistical analysis}

Studies meeting the inclusion criteria were examined and study demographics (age, gender, type of dancers, setting) as well as information about eating disorders (prevalence data, mean scores of questionnaires) were recorded. The articles were divided into subgroups of controlled and uncontrolled studies. A study was considered controlled if the prevalence of eating disorders or the results of the questionnaires in dancers was compared to non-dancers. Eating disorder was assessed using structured and semi-structured diagnostic interviews and diagnosed according to the Diagnostic and Statistical Manual of Mental Disorders (DSM; APA, 1952-2000) that was current at the time of the study. In the majority of the studies, the severity of the eating disorders was assessed by self-report symptoms scales (e.g., EAT, EDI, or EDE-Q). In some of these studies, caseness was determined by scores above a specific threshold of the EAT. Here, these individuals will be described as possibly suffering from an eating disorder.

There were two outcomes of interest; 1) the number of dancers diagnosed with an eating disorder at the time of study (point prevalence), and 2) the mean results of the different questionnaires describing eating disorder psychopathology (mean severity). The primary data of the epidemiological studies describing eating disorders in dancers was extracted as raw numbers. For the purpose of this analysis, study design was explored as a dichotomous variable. Risk ratios (RRs) were calculated only for controlled studies, because these calculations derived from comparing the risk of eating disorders in dancers with the risk in the non-dancers group. For those studies describing only mean results of their questionnaires, the effect size for the continuous variables was calculated. An aggregate effect size weighted by sample size was computed to provide an overall effect size across the studies. Homogeneity among studies was computed using the $\mathrm{Q}$ statistic and the $I^{2}$ statistic. A significant $\mathrm{Q}$ statistic suggests that the distribution of effect size around the mean is greater than would be 
predicted from sampling error alone, whereas $I^{2}$ provides an estimate of the proportion of the variance in the aggregate effect size that is attributable to between-studies heterogeneity (Higgins \& Thompson, 2002). Random-effects models were fitted if there was heterogeneity. Risk ratios and 95\% confidence intervals (Cls) were calculated. The relative weighted contribution of each study, as well as the risk ratio estimate pooled across all studies, were also assessed. Meta-analysis was performed using the Comprehensive Meta-Analysis software programme-2 for Windows (CMA; Borenstein, Hedges, Higgins, \& Rothstein, 2005) according to the Cochrane reviewers' handbook (Higgins \& Green, 2011). Significance was set up at $p<0.05$. As the outcomes of interest were prevalence and severity, not the effect of certain factors such as age or country where the study was conducted, metaregression analysis and grouping were not used.

\section{Included and excluded studies}

Two independent assessors (JA and GLW) identified 91 relevant articles, which were screened in detail. Following this, 50 papers were excluded. The reasons for the exclusions were: non-English publication (with no English abstract; $n=7$ ); conference only paper with paper not printed in a peer reviewed journal $n=8$ ); inadequate sample size (less than 10 patients; $n=3$ ); lack of tools used to measure eating psychopathology $(n=28)$, and not involving dancers but involving aerobic teaches or skaters only ( $n=3)$. Out of the 42 papers retrieved for more detailed evaluation, eight were excluded for having no description of eating disorders and/or not using tools to measure eating disorder psychopathology (not identifiable through the abstract). In total 33 studies were reviewed systematically.

\section{Summary of relevant studies}

Thirty-three relevant empirical quantitative studies in eating disorders or eating problems in dancers were published between 1966 and 2013. The oldest study was from 1985 (Szmuklet, Eisler, Gillies, \& Hayward, 1985) and the most recent one from 2012 (Nascimiento \& Fontenelle, 2012). Twenty-three (69.7\%) papers included exclusively ballet dancers, nine (27.3\%) included general dancers and one 
(3\%) Turkish dancers (Batur, Kabakci, \& Gulol, 2003). Only five papers (16.1\%) included men. Those studies were not used to calculate meta-analytical means. Thirteen (39.4\%) studies were European: three Italian (Dotti et al., 2002; Ravaldi et al., 2003; Ravaldi et al., 2006), two from the UK (Szmukler, Eisler, Gillies, \& Hayward, 1985), two from Germany (Bettle, Bettle, Neumaker, \& Neumaker, 1998; Herbrich et al., 2011) and one study from each of the following European countries: Netherlands (Fogelholm, Van Marken Lichtenbelt, Ottenheijm, \& Westerterp, 1996), France (Martin \& Bellisle, 1989), Spain (Toro et al., 2009), Switzerland (Burckhardt, Wynn, Kreig, Bagutti, \& Faouzi, 2011), Portugal (Francisco, Narciso, \& Alarcao, 2012), and Belgium (Van Durme, Goossens, \& Braet, 2012). Twelve (36.4\%) studies were from North America; one from Canada (Piran, 1999) and 11 from the USA. Of the remaining papers, three (9.1\%) were Australian (Abraham, 1996; Anshel, 2004; Penniment \& Egan, 2012), two (6.1\%) were Brazilian (Riberio \& da Veiga, 2010; Nascimento \& Fontenelle, 2012), one was Taiwanese (Tseng et al., 2007), one was Turkish (Batur et al., 2003) and one was South African (Le Grange et al., 1994). Twelve (36.4\%) studies involved professional dancers only: 10 (30.3\%) ballet dancers and two (6.1\%) general dancers. Three (9.1\%) studies included professional and amateur dancers together (two with ballet dancers and one with Turkish dancers) however the authors of these studies present the results separately for professionals and amateurs. The rest of the studies $(57.6 \%, n=19)$ included students, 14 of them from ballet schools. Among the studies from students, 12 (36.4\%) provided eating disorders information from students attending elite dance schools (10 of them from ballet schools) and the rest $(21.2 \%, n=7)$ from non-elite schools (four from ballet schools). In view of the small number of studies describing males and the low sample size and power in this subgroup, only studies including females were selected for the overall analysis. In view of the large number of studies describing ballet dancers, the results of this population will be shown separately.

\section{Results}




\section{General descriptive statistics}

The total number of dancers that participated in the studies was 3337. The mean age of participants was 19.5 years (SD=5.76; minimum and maximum mean age was 12.6 and 38 years, respectively). The number of participants included in the studies varied greatly from 13 to 665.

There were considerable differences among the studies in design, group size and methods. Nearly a quarter of the studies $(n=8,24.2 \%)$ offered prevalence data on clinical eating disorders using a validated structured interview. Most of the studies used eating disorders questionnaires (mainly the Eating Attitude Test [EAT]) which does not prove a diagnosis but gives information on eating disorder psychopathology. Twenty studies (60.6\%) used a control group to compare their results; either healthy controls ( $n=12,36.4 \%)$, a different group of dancers $(n=6,18.2 \%)$, or other athletes (gymnasts, bodybuilders or gym users; $n=2,6.1 \%)$.

\section{Point prevalence of eating disorders}

\section{All dancers vs non-dancers}

Seven studies used a diagnostic interview in order to identify point prevalence of eating disorders in general. Eight studies used it to identify point prevalence for anorexia, six for bulimia and six for EDNOS. Except for one study, which described the prevalence of eating disorders in general dancers from Taiwan (Tseng et al., 2007), all of the remaining studies included ballet dancers only. The overall prevalence of eating disorders using random effects meta-analysis was $12.0 \%(95 \% \mathrm{Cl}$, 10.0-14.2). For anorexia it was $2.0 \%(95 \% \mathrm{Cl}, 0.9-4.3)$, for bulimia it was $4.4 \%(95 \% \mathrm{Cl}, 3.2-6.2)$ and for EDNOS it was 9.5\% (95\% Cl, 7.6-11.8). Eleven studies described the prevalence of possible cases of eating disorders among dancers using caseness from the results of one questionnaire. The questionnaire used was the Eating Attitude Test (EAT; 40 or 26), which described caseness when individuals score above 30 for the EAT-40 and above 20 for the EAT-26. These questionnaires have been very popular in this field, as more than half of the studies $(n=18,58 \%)$ used them. Some studies used the EAT with the aim of identifying possible cases of eating disorders as this usually needs to be 
followed by an interview in order to reach a diagnosis. Most of the studies did not aim to measure the prevalence of eating disorders but to identify a correlation between disordered eating and other variables, such as menstruation or bone density. Seven of those studies included ballet dancers only. The prevalence of possible cases of eating disorders in professional dancers ranged from 0 to $13.6 \%$ for males (only 2 studies) and from $7.4 \%$ to $50 \%$ in females.

\section{Ballet dancers vs non-dancers}

Six studies used diagnostic interviews in order to identify current prevalence rates of eating disorders among ballet dancers. The overall number of individuals involved in those studies were 484 ballet dancers, with an overall mean age of 16.7 years $(S D=1.13)$, ranging from 15.6 years to 18.9 years. The maximum number of individuals in one single study was 113 (Ravaldi et al., 2003). All of the individuals were students. The prevalence of eating disorders in ballet dancers ranged from 1.90 to $26.60 \%$. The overall prevalence of eating disorders using random effects meta-analysis was 16.4 (95\% Cl, 13.1-20.5). Lower prevalence was identified in studies using non-specifically designed eating disorders diagnostic interviews (general DSM interviews). There were also a higher number of cases suffering from eating disorders among students not attending elite ballet schools although this was not statistically assessed. The prevalence for anorexia nervosa ranged from 0.9 to $4.1 \%$ and for bulimia nervosa from 0 to $2.7 \%$. The overall prevalence of anorexia nervosa using random effect metaanalysis was $4.0(95 \% \mathrm{Cl}, 2.3-6.7)$ and for bulimia $2.0(95 \% \mathrm{Cl}, 0.9-4.3)$. The lower prevalence of $\mathrm{BN}$ may be explained by the fact that this disorder tends to develop at a later age. As expected, there was a high number of EDNOS cases (between 8.3 and 22.10\%). The overall prevalence of EDNOS among ballet dancers was $14.9(95 \% \mathrm{Cl}, 11.3-19.4)$. Some of those cases may have been diagnosed as AN or BN under the current DSM-V diagnosis (APA, 2013).

Three studies, which included professional ballet dancers, measured lifetime prevalence of eating disorders (Holderness, Brooks-Gunn, \& Warren, 1994; Ringham et al., 2006; Nascimiento \& Fontenelle, 2012). The lifetime prevalence found in professional ballet dancers ranged from 15.78 to 
82.6\%. This large variation can be explained by the number of EDNOS cases found in one of the studies (72\%; Ringham et al., 2006). The lifetime prevalence for anorexia nervosa ranged from 3.4 to $31 \%$ and for bulimia nervosa from 6.90 to $12 \%$.

\section{Prevalence of possible cases of eating disorders based on questionnaire results}

Seven studies described the prevalence of possible cases of eating disorders among ballet dancers using caseness. Four of the seven studies describing caseness included professional ballet dancers and three involved students from elite ballet schools. The prevalence of possible cases of eating disorders in professional dancers was $13.6 \%$ for males (one study) and ranged from 10.3 to $73.10 \%$ in females.

Insert table 2 around here

Insert table 3 around here

(Figure 1,2,3,4)

Severity of eating psychopathology - mean results of questionnaires

\section{All dancers vs non-dancers}

Seven studies used the EAT-40. The mean overall meta-analytical score was 22.73 $(S E D=0.46)$. However, there was large variation in the mean scores among the dancers in these studies ranging from 17.9 to 51.2 . This variation could be explained by the differences in the populations studied. There was a similar variation of means of the EAT-26 (meta-analytical mean score $=3.54, \mathrm{SED}=0.07$ ) ranging from 2.37 to 22.90 . However this variation cannot be explained by mean age, whether the dancers were students or professionals, or by the country where the study took place. Seven studies used the EDI to identify eating disorder psychopathology. The overall mean EDI was 46.59 (SED=0.60). The mean EDI is rarely used in the eating disorders literature and scores on the different eating disorders risk composite scales (drive for thinness [DT], bulimia [B], and body dissatisfaction $[B D]$ ) are more commonly reported. The overall mean for DT was 6.21 (SED=0.21), for 
B was $0.82(S E D=0.05)$ and for BD was 13.06 (SED=0.25). Only three studies used the EDE-Q. The mean score of the EDE-Q was 1.58 (SED=0.07).

\section{Ballet dancers vs non-dancers}

Mean EAT-40 scores were available from three studies and seven studies provided mean EAT-26 scores. Total EDI scores and scores on the sub-scales of Drive for Thinness (DT) and Bulimia (B) were available from seven studies. Scores on the EDI Body Dissatisfaction (BD) sub-scale were available from four studies and EDE-Q mean scores were also available from four studies. Some of the studies report mean scores in different subgroups (i.e., primary and secondary students, or dancers attending national, regional and local competitions; Piran [1999], and Thomas, Keel, \& Heatherton [2005], respectively) which were analysed separately. The meta-analytical mean score of the EAT-40 was $27.42(\mathrm{SED}=12.5)$ and for the EAT-26 it was 3.03 (SED=0.07). The mean score for the total EDI was 46.59 (SED=0.60). The DT subscale mean was $15.78(\mathrm{SED}=1.90)$, the B subscale mean was $10.12(\mathrm{SED}=2.47)$ and the $\mathrm{BD}$ subscale mean was 17.24 (SED=0.31). The EDE-Q metaanalytic mean score was 1.07 (SED=0.58).

Insert table 4 around here

Relative risk of eating disorders in dancers vs non-dancers

Meta-analysis was performed using only studies that provided control data. Studies that provided control data from other athletes such as gym users or gymnast were not included as high levels of eating disorders have already been reported in athletes.

Only five studies had enough information for the meta-analysis to be carried out. They included a total of 948 dancers and 1619 non-dancers. Heterogeneity was low $\left(I^{2}=0 \%\right)$ and the analysis showed that dancers had a higher risk of suffering from eating disorders in general $(R R=2.56, z=5.83, p=0.0001)$; in anorexia nervosa $(R R=3.60, z=2.28, p=0.02)$; and in EDNOS $(R R=3.02, z=5.25, p=0.0001)$. The 
risk of developing bulimia was not statistically significantly higher in dancers when comparing to nondancers $(\mathrm{RR}=1.29, \mathrm{z}=1.21, p=0.26)$.

Only four studies provided enough control data to examine the risk of suffering from an eating disorder in ballet dancers compared to non-dancers. They included a total of 335 ballet dancers and 438 nondancers. Heterogeneity was low $\left(I^{2}=0 \%\right)$. A statistically significantly higher risk for eating disorders in general $(\mathrm{RR}=1.78, z=2.70, p=0.007)$ and for EDNOS $(\mathrm{RR}=2.12, z=2.90, p=0.004)$ was found among ballet dancers. No differences were found for anorexia $(R R=3.85, z=1.68, p=0.09)$ or for bulimia $(\mathrm{RR}=0.62, \mathrm{z}=-0.9, p=0.36)$.

There were only three studies using control data for the EAT-26 and for the EDI. Meta-analysis was used to compare the mean scores of the questionnaires between all dancers and non-dancers in these studies. The scores in the dancer group were statistically significantly higher for all the questionnaires: EAT-26 ( $z=13.31, p=0.001)$, EDI-DT ( $z=8.61, p=0.001)$, EDI-B ( $z=4.79)$, and EDI-BD $(z=6.144, p=0.001)$. There were not enough control studies to use meta-analysis to compare questionnaires results of just the ballet dancers (as opposed to all dancers) with non-dance controls.

\section{Discussion}

The aim of the study was to systematically summarise the available literature in the field of eating disorders and dance. We were able to identify 33 studies describing eating disorder diagnosis or reporting mean values of questionnaires aimed at measuring eating disorder psychopathology. As per any meta-analysis, the study is limited by the amount of studies available in the field. Although the overall number of studies appears to be substantial $(n=33)$ when examining the available data there was a small number of studies that were suitable for a proper meta-analysis. Previous studies could be criticised by the fact that different populations and variables have been compared. This study aimed to compare a group of subjects as homogeneous as possible. As a result, the study is strengthen by the homogeneity of the population selected (female dancers or female ballet dancers) 
and the variables collected (only studies that report eating disorders prevalence using strong methodology, such as semi-structured interviews). However, as a result, it has been limited by the small number of studies available and the small populations studied. Therefore the results of the study need to be considered within these limitations.

The overall prevalence of eating disorders in all dancers was found to be $12 \%$, which was slightly lower than the prevalence found in ballet dancers (16.4\%). The difference appeared to be particularly related to the high number of EDNOS (14.9\%) and anorexia (4\%) cases found among ballet dancers. A strength of this analysis is the fact that this group is very homogeneous, all of them are female and ballet students. In that respect it appears that nearly one fifth of ballet dance students suffer from an eating disorder, predominantly from the EDNOS type. When comparing the result of ballet students with non-dancers, we found that ballet students had a significantly higher risk of suffering from eating disorders, particularly EDNOS. In fact they had twice the chance of developing EDNOS when compared to non-dancers. Unfortunately there was not enough information about the type of EDNOS. Research has identified that individuals suffering from EDNOS of anorexia subtype present no significant differences in eating related and general psychopathology when compared to those suffering from anorexia nervosa (Le Grange et al., 2013). In fact, some of the dancers suffering from EDNOS may have been diagnosed with anorexia nervosa under the new DSM-V diagnostic criteria (APA, 2013). Interestingly no significant difference was found in anorexia or bulimia rates. The former may be explained by the rarity of the disease and the low number of studies in the field, while the latter may be explained by the age of the population studied as this disorder tends to appear at a later age.

The results were slightly different when comparing all dancers with non-dancers. The population of dancers that has been involved in these studies is too diverse to reach full conclusions as they incorporate different types of dance (e.g., ballet, jazz, national) and spanning levels from students to professionals. Therefore these results need to be considered with caution and generalisability may be difficult. Nevertheless, our results showed that general dancers had more than twice the risk of 
developing an eating disorder and more than three times the risk of developing anorexia nervosa and EDNOS than non-dancers. In spite of the limited number of questionnaire studies that used control data when assessing eating disorder psychopathology, our analysis found a significant difference on the Eating Attitudes Test (EAT-26) and the Drive for Thinness, Bulimia, and Body Dissatisfaction subscales of the Eating Disorders Inventory (EDI). Body dissatisfaction and general body shame has been found to predict an increase in anorexic symptoms but interestingly not bulimic symptoms (Troop \& Redshaw, 2012).

Although this study did not compare ballet dancers with all dancers (which would include some dancers who do ballet as well as other dance) due to the limited number of control studies comparing ballet with general dancers, it is interesting that there appears to be a difference in the subscales of the EDI between the two groups, indicating that ballet dancers present with higher levels of drive for thinness, bulimia and body dissatisfaction. Further research in this area will be able to explore the reason for this. For example, do ballet students have a pre-existing elevated risk of developing an eating disorder before they become involved in ballet, or is it a result of the environment? Research into physical injuries in dancers has found that both professional and amateur dancers have a tendency to normalise pain (Markula, 2013). The belief that if no pain is felt, then the dancers are not pushing themselves hard enough appears to be commonplace (Turner \& Wainright, 2003). A similar drive to push oneself to achieve the desired 'dancer's body', irrespective of how hard this may be, may possibly play a role in the higher levels of eating disorders seen in ballet dancers.

\section{Limitations and future studies}

This analysis has a number of limitations. Notably we were reliant on the quality and non-repetition of primary publications. We sought to ensure data integrity by excluding small studies of less than 10 patients. As a result, the resulting study is limited by the number of available published data for this population and whilst the data were reasonably robust for ballet dancers, the population of other dancers was non-homogenous and mixed. Throughout the years, investigators have used a large 
number of different diagnostic and outcome assessment measures, which have reflected numerous definitions of diagnosis. The lack of consistency in the measures used makes comparisons across studies very difficult. Consolidation of measures, standardised definitions and reporting guidelines are critical to the further advancement of the field. The weakness of most of the studies used in this metaanalysis is that they aim to measure eating disorder psychopathology by studying its relationship with other factors, such as menstruation or injuries. The number of epidemiological studies in the field of dance are few, possibly due to the complexity of undertaking such studies and the secrecy of the disorder. However, dance organisations such as Dance UK have started to highlight the need for such studies in order to identify the need for clinical services linked to dancers. Dancers suffering from physical injuries are treated within specialist clinical services. It can be argued then that as eating disorders are found to be considerably more prevalent in this population, dancers should also have access to dance-specific eating disorders services. Advances in technology provide opportunities for the ways in which self-help can be delivered (e.g., Cardi, Clarke, \& Treasure, 2013) which could be tailored to dancers. Alternatively, specifically designed preventative programmes, as described in other populations (Beintner, Jacobi, \& Taylor, 2012) may reduce levels of eating disorders in dancers. A well-performed epidemiological study in the dance world using diagnostic interviews and controlling for age and type of dance may be able to address the question of whether and how the presentation of eating disorders in dancers differs from non-dancers. 


\section{References}

Abraham, S. (1996). Characteristics of eating disorders among young ballet dancers. Psychopathology, 29, 223-229.

Anshel, M.H. (2004). Sources of disordered eating patterns between ballet dancers and non-dancers. Journal of Sport Behaviour, 27(2), 115-133.

American Psychiatric Association (1952; 1968; 1980; 1987; 2000; 2013). Diagnostic and statistical manual of mental disorders $\left(1^{\text {st }}, 2^{\text {nd }}, 3^{\text {rd rev }}, 4^{\text {th }}, 4^{\text {th rev }}, \& 5^{\text {th }}\right.$ editions, respectively $)$. Washington, DC: America Psychiatric Association.

Arcelus, J., Haslam, M., Farrow, C., \& Meyer, C. (2013). The role of interpersonal functioning in the maintenance of eating psychopathology: A systematic review and testable model. Clinical Psychology Review, 33, 156-167.

Batur, S., Kabakci, E., \& Gulol, C. (2003). Maladaptive eating attitudes of elite and amateur Turkish dancers: Are they at risk? Eating and Weight Disorders, 8, 263-267.

Beintner, I., Jacobi, C., \& Taylor, C.B. (2012). Effects of an internet-based prevention programme for eating disorders in the USA and Germany: A meta-analytic review. European Eating Disorders Review, 20, 1-9.

Benn, T., \& Walters, D. (2001). Between scylla and charybdis nutritional education versus body culture and the ballet aesthetic: The effects on the lives of female dancers. Research in Dance Education, 2, 139-155.

Bettle, N., Bettle, O., Neumaker, U., \& Neumaker, K.J. (1998). Adolescent Ballet School Students: Their Quest for Body Weight Change. Psychopathology, 31, 153-159.

Borenstei, M., Hedges, L., Higgins, J., \& Rothstein, H. (2005). Comprehensive meta-analysis. Version 2, Biostat, Englewood NJ.

Brooks-Gunn, J., Warren, P., \& Hamilton, L.H. (1986). The relation of eating problems and amenorrhea in ballet dancers. Medicine and Science in Sports and Exercise, 19(1), 41-44. 
Burckhardt, P., Wynn, E., Kreig, M-A., Bagutti, C., \& Faouzi, M. (2011). The effects of nutrition, puberty and dancing on bone density in adolescent ballet dancers. Journal of Dance Medicine and Science, 15(2), 51-60.

Cardi, V., Clarke, A., \& Treasure, J. (2013). The use of guided self-help incorporating a mobile component in people with eating disorders: A pilot study. European Eating Disorders Review, 21(4), 315-322.

Dotti, A., Fioravanti, A., Balotta, M., Tozzi, F., Cannella, C., \& Lazzari, R. (2002). Eating behavior of ballet dancers. Eating and Weight Disorders, 7, 60-67.

Evers, C.L. (1987). Dietary intake and symptoms of anorexia nervosa in female university dancers. Perspectives in Practice, 87(1), 66-68.

Fairburn, C.G. \& Beglin, S.J. (1994). Assessment of eating disorder psychopathology: interview or self-report questionnaire? International Journal of Eating Disorders, 16, 363-370.

Francisco, R., Narciso, I., \& Alarcao, M. (2012). Specific predictors of disordered eating among elite and non-elite gymnasts and baller dancers. International Journal of Sport Psychology, 43, 479502.

Fogelholm, M., Van Marken Lichtenbelt, W., Ottenheijm, R., \& Westerterp, K. (1996). Amenorrhea in ballet dancers in the Netherlands. Medicine and Science in Sports and Exercise, 28(5), 545550.

Garner, D. M., Olmsted, M. P., Bohr, Y., \& Garfinkel, P. E. (1982). The Eating Attitude Test: Psychometric features and clinical correlates. Psychological Medicine, 12, 871-878.

Garner, D.M., Olmstead, M.P., \& Polivy, J. (1983). Development and validation of a multidimensional eating disorder inventory for anorexia nervosa and bulimia. International Journal of Eating Disorders, 2(2), 15-34.

Gunnard, K., Krug, I., Jimenez-Murcia, S., Penelo, E., Granero, E., Treasure, J. et al., (2012). Relevance of social and self-standards in eating disorders. European Eating Disorders Review, 20, 271- 279 . 
Hamilton, L.H., Brooks-Gunn, J., Warren, M.P., \& Hamilton, W.G. (1988). The role of selectivity in the pathogenesis of eating problems in ballet dancers. Medicine and Science in Sports and Exercise, 20(6), 560-565.

Herbrich, L., Pfeiffer, E., Lehmkuhl, U., \& Schneider, N. (2011). Anorexia athletica in pre-professional ballet dancers. Journal of Sports Sciences, 29(11), 1115-1123.

Hoek, H.W., \& Van Hoeken, D. (2003). Review of the prevalence and incidence of eating disorders. International Journal of Eating Disorders, 34, 383-96.

Holderness, C.C., Brooks-Gunn, J., \& Warren, M.P. (1994). Eating disorders and substance use: a dancing vs a nondancing population. Medicine and Science in Sports and Exercise, 26(3), 297302.

Higginis, J.P.T., \& Green, S. (2011). Cochrane handbook for systematic reviews of interventions. The Cochrane collaboration. www.cochrane-handbook.org

Higgins, J.P.T. \& Thompson, S.G. (2002). Quantifying heterogeneity in a meta-analysis. Statistics in Medicine, 21, 1539-15558.

Kaufman, B.A., Warren, M.P., Domingues, J.E., Wang, J., Heymsfield, S.T., \& Pierson, R.N. (2002). The Journal of Clinical Endocrinology and Metabolism, 87(6), 2777-2783.

Le Grange, D., Crosby, R.D., Engel, S.G., Cao, L., Ndungu, A., Crow, S.J. et al. (2013). DSM-IVDefined anorexia nervosa versus sub threshold anorexia nervosa (EDNOS-AN). European Eating Disorders Review, 21, 1-7.

Le Grange, D., Tibbs, J., \& Noakes, T.D. (1994). Implications of a diagnosis of anorexia nervosa in a ballet school. International Journal of Eating Disorders, 15(4), 369-376.

Markula, P. (2013). (Im)Mobile bodies: Contemporary semi-professional dancers' experiences with injuries. International Review for the Sociology of Sport. Published online before print. DOI: $10.1177 / 1012690213495745$

Martin, C. \& Bellisle, F. (1989). Eating attitudes and taste responses in young ballerinas. Physiology and Behavior, 46, 223-227.

Nascimento, A.L. \& Fontenelle, L.F. (2012). Body dysmorphic disorder and eating disorders 
in elite professional female ballet dancers. Annals of Clinical Psychiatry, 24, 191-194.

Nordin-Bates, S. M., Cumming, J., Sharp, L., \& Aways, D. (2011). Imagining yourself dancing to perfection? Cognitive correlates of perfectionism among ballet and contemporary dancers. Journal of Clinical Sport Psychology, 5, 58-76.

Nordin-Bates, S.M., Walker, I.J., \& Redding, E. (2011). Correlates of disordered eating attitudes among male and female young talented dancers: Findings from the UK Centres for Advanced Training. Eating Disorders, 19, 211-233.

Penniment, K.I. \& Egan, S.J. (2012). Perfectionism and learning experiences in dance class as risk factors for eating disorders in dancers. European Eating Disorders Review, 20, 13-23.

Piran, N. (1999). Eating disorders: A trial of prevention in a high risk school setting. The Journal of Primary Prevention, 20(1), 75-90.

Preti, A., De Girolamo, G., Vilagut, G., Alonso, J., Graaf, R.D., Bruffaerts, R., et al. (2009). The epidemiology of eating disorders in six European countries: Results of the ESEMeD-WMH project. Journal of Psychiatric Research, 43, 1125-1132.

Ravaldi, C., Vannacci, A., Zucchi, T., Mannucci, E., Cabras, P.L., Boldrin, M., et al. (2003) Eating disorders and body image disturbances among ballet dancers, gymnasium users and body builders. Psychopathology, 36, 247-254.

Ravaldi, C., Vannacci, A., Bolognesi, E., Mancini, S., Faravelli, C., \& Ricca, V. (2006). Gender role, eating disorder symptoms, and body image concern in ballet dancers. Journal of Psychosomatic Research, 61, 529-535.

Ribeiro, L.G. \& da Veiga, G.V. (2010). Risk behaviors for eating disorders in Brazilian dancers. International Journal of Sports Medicine, 31, 283-288.

Ringham, R., Klump, K., Kaye, W., Stone, D., Libman, S., Stowe, S., et al. (2006). Eating disorder symptomatology among ballet dancers. International Journal of Eating Disorders, 39(6), 503508.

Schnitt, J.M., Schnitt, D., \& Del A'Une, W. (1986). Anorexia nervosa or thinness in modern dance students: comparison with ballerinas. Annuals of Sports Medicine, 31(1), 9-13. 
Smethurst, W., Wales, J., \& Arcelus, J. (2010). Puff the magic slimmer. European Eating Disorders Review, 18, 431-433.

Sundgot-Borgen, J. \& Torstveit, M.K. (2004). Prevalence of eating disorders in elite athletes is higher than in the general population. Clinical Journal of Sport Medicine, 14(1), 25-32.

Szmukler, G.I., Eisler, I., Gillies, C., \& Hayward, M.E. (1985). The implication of anorexia nervosa on a ballet school. Journal of Psychiatric Research, 17, 177-181.

Thomas, J.J., Keel, P.K., \& Heatherton, T.F. (2005). Disordered eating attitudes and behaviors in ballet students: Examination of environmental and individual risk factors. International Journal of Eating Disorders, 38(3), 263-268.

Toro, J., Guerrero, M., Sentis, J., Castro, J., \& Puertolas, C. (2009). Eating disorders in ballet dancing students: Problems and risk factors. European Eating Disorders Review, 17, 40-49.

Troop, N.A. \& Redshaw, C. (2012). General shame and bodily shame in eating disorders: A 2.5 years longitudinal study. European Eating Disorders Review, 20, 373- 378.

Tseng, M.M-C., Fang, D., Lee, M-B., Chie, W-C., Liu, J.P., \& Chen, W.J. (2007). Two-phase survey of eating disorders in gifted dance and non-dance high-school students in Taiwan. Psychological Medicine, 37, 1085-1096.

Turner, B.S. \& Wainright, S.P. (2003). Corps de ballet: The case of the injured ballet dancer. Sociology of Health \& IIIness, 25(4), 269-288.

Van Durme, K., Goossens, L., \& Braet, C. (2012). Adolescent aesthetic athletes: A group at risk for eating pathology? Eating Behaviors, 13, 119-122.

Zoletić, E., \& Duraković-Belko, E. (2009). Body image distortion, perfectionism and eating disorder symptoms in risk group of female ballet dancers and models and in control group of female students. Psychiatria Danubina, 21(3), 302-309. 

Table 1: Criteria for searches on eating disorders and dance

\begin{tabular}{|c|c|}
\hline Category & Criteria \\
\hline Study population & $\begin{array}{l}\text { Humans } \\
\text { All races, ethnicities, and cultural groups } \\
\text { All ages }\end{array}$ \\
\hline Study settings and geography & All nations \\
\hline Time period & Published from 1966 through July 2013 \\
\hline Publication criteria & $\begin{array}{l}\text { Included: } \\
\text { - English } \\
\text { - Articles in print } \\
\text { Excluded: } \\
\text { - Articles in grey literature or non-peer-reviewed journals or } \\
\text { unobtainable during the review period }\end{array}$ \\
\hline $\begin{array}{l}\text { Admissible evidence } \\
\text { (study design and } \\
\text { other criteria) }\end{array}$ & $\begin{array}{l}\text { - AN must be diagnosed according to DSM I, II, III, DSM III-R, } \\
\text { DSM IV, ICD-10, Feighner, or Russell criteria. } \\
\text { - BN must be diagnosed according to DSM I, II, III, III-R, DSM } \\
\text { IV, or ICD-10 criteria. } \\
\text { - EDNOS or Atypical eating disorders must be diagnosed } \\
\text { according to DSM III and DSM IV criteria. } \\
\text { Eligible study designs include outcomes studies; } \\
\text { observational studies including prospective and retrospective } \\
\text { cohort studies. } \\
\text { Populations must include } 10 \text { or more participants (in total) at } \\
\text { the time of analysis. }\end{array}$ \\
\hline
\end{tabular}


Table 2: Eating disorders in dancers

\begin{tabular}{|c|c|c|c|c|c|c|c|c|c|c|c|c|c|}
\hline Year & Author & Country & $\mathbf{N}$ & M/F & $\begin{array}{l}\text { Mean } \\
\text { Age }\end{array}$ & $\begin{array}{l}\text { Type } \\
\text { Dance }\end{array}$ & Setting & Tools & $\begin{array}{l}\text { Life } \\
\text { time }\end{array}$ & $\begin{array}{l}\text { ED } \\
\text { (\%) }\end{array}$ & $\begin{array}{l}\text { AN } \\
\text { (\%) }\end{array}$ & $\begin{array}{l}\mathrm{BN} \\
(\%)\end{array}$ & $\begin{array}{l}\text { EDNOS } \\
\text { (\%) }\end{array}$ \\
\hline 1985 & Szmukler et al. & UK & 100 & $f$ & 15.6 & Ballet & Elite students & $\begin{array}{l}\text { EAT-26 } \\
\text { Clinical Interview }\end{array}$ & $\mathrm{n} / \mathrm{a}$ & 7 & 7 & $\mathrm{n} / \mathrm{a}$ & $\mathrm{n} / \mathrm{a}$ \\
\hline 1994 & Le Grange et al. & S Africa & 49 & $f$ & 18.9 & Ballet & Elite students & $\begin{array}{l}\text { EAT-40 } \\
\text { Clinical Interview (DSM-III) }\end{array}$ & $\mathrm{n} / \mathrm{a}$ & 12.3 & 4.1 & 0 & $\mathrm{n} / \mathrm{a}$ \\
\hline 1994 & $\begin{array}{l}\text { Holderness et } \\
\text { al. }\end{array}$ & USA & 50 & $f$ & 20.9 & Ballet & Professionals & $\begin{array}{l}\text { EAT-26 } \\
\text { Clinical interview (DSM-III) }\end{array}$ & 43 & $\mathrm{n} / \mathrm{a}$ & 31 & 12 & $\mathrm{n} / \mathrm{a}$ \\
\hline 1996 & Abraham & Australia & 60 & $f$ & 16.9 & Ballet & Elite students & Clinical Interview (DSM-III) & $\mathrm{n} / \mathrm{a}$ & 11.5 & 1.6 & 1.6 & 8.3 \\
\hline 2003 & Ravaldi et al. & Italy & 113 & $f$ & 16.2 & Ballet & Non elite students & EDE & $\mathrm{n} / \mathrm{a}$ & 26.6 & 1.8 & 2.7 & 22.1 \\
\hline 2006 & Ringham et al. & USA & 29 & $f$ & 19.7 & Ballet & Professionals & EDI I\& SCID Interview & 83 & $\mathrm{n} / \mathrm{a}$ & 3.4 & 6.9 & 72.3 \\
\hline 2006 & Ravaldi et al. & Italy & 110 & $f$ & 16.5 & Ballet & Non elite students & EDE & $\mathrm{n} / \mathrm{a}$ & 13.6 & 0.9 & 1.8 & 10.9 \\
\hline 2007 & Tseng et al. & Taiwan & 613 & $f$ & 15.8 & General & Elite school students & $\begin{array}{l}\text { EAT-26 } \\
\text { SCID Interview }\end{array}$ & $\mathrm{n} / \mathrm{a}$ & 8 & 0.7 & 2.5 & 4.8 \\
\hline 2009 & Toro et al. & Spain & 76 & $\bar{f}$ & 14.4 & General & Non elite students & EAT-26 \& CETCA & $\mathrm{n} / \mathrm{a}$ & $\mathrm{n} / \mathrm{a}$ & $1.3^{*}$ & $15.8^{*}$ & $\mathrm{n} / \mathrm{a}$ \\
\hline 2011 & Herbrich et al. & Germany & 52 & $f$ & 16.4 & Ballet & Elite students & $\begin{array}{l}\text { EDI I } \\
\text { SCID Interview }\end{array}$ & $\mathrm{n} / \mathrm{a}$ & 1.9 & 0 & $\mathrm{n} / \mathrm{a}$ & 73.1 \\
\hline 2012 & $\begin{array}{l}\text { Nascimento \& } \\
\text { Fontenelle }\end{array}$ & Brazil & 19 & $f$ & 34.4 & Ballet & Professional & $\begin{array}{l}\text { Interview (DSM-IV) } \\
\text { BITE }\end{array}$ & 15.7 & $\mathrm{n} / \mathrm{a}$ & $\mathrm{n} / \mathrm{a}$ & $\mathrm{n} / \mathrm{a}$ & $\mathrm{n} / \mathrm{a}$ \\
\hline
\end{tabular}

F: Female, n/a: not available; SCID: Structured Clinical Interview for DSM Axis I Disorders; EDE: Eating Disorders Examination; CETCA: Eating disorders assessment questionnaire; BITE: Bulimia investigation test Edinburgh; * probable anorexia or bulimia nervosa 
Table 3: Meta-analytical prevalence of eating disorders and meta-analytical means of questionnaires

\begin{tabular}{|l|c|c|}
\hline & Ballet dancers & All dancers \\
& $\mathrm{n}=1729=3337$ \\
\hline Mean age & 20.34 years & 18.78 years \\
\hline Eating disorders & $16.4 \%$ & $12.0 \%$ \\
\hline Anorexia Nervosa & $4 \%$ & $2.0 \%$ \\
\hline Bulimia Nervosa & $2 \%$ & $4.4 \%$ \\
\hline EDNOS & $14.9 \%$ & 22.73 \\
\hline Mean EAT-40 & 27.42 & 3.54 \\
\hline Mean EAT-26 & 3.03 & 46.59 \\
\hline Mean EDI & 46.59 & 6.21 \\
\hline Drive for thinness (EDI) & 15.78 & 0.82 \\
\hline Bulimia (EDI) & 10.12 & 13.06 \\
\hline Body dissatisfaction (EDI) & 17.24 & 1.58 \\
\hline EDE-Q & 1.07 & \\
\hline
\end{tabular}

EDNOS: Eating disorders not otherwise specified; EAT: Eating Attitude Test; EDI: Eating disorders Inventory; EDEQ: Eating Disorders Examination Questionnaire; 
Table 4: Mean scores of the eating disorders questionnaires in dancers

\begin{tabular}{|c|c|c|c|c|c|c|c|c|c|c|c|c|c|c|c|c|c|}
\hline Year & Author & Country & $\mathbf{N}$ & $\begin{array}{l}\mathrm{M} / \\
\mathrm{F}\end{array}$ & $\begin{array}{l}\text { Mean } \\
\text { Age }\end{array}$ & Dance & Setting & Tools & $\begin{array}{l}\text { Case- } \\
\text { ness for } \\
\text { EAT }\end{array}$ & $\begin{array}{l}\text { EAT } \\
-40\end{array}$ & $\begin{array}{l}\text { EAT- } \\
26\end{array}$ & EDI & $\begin{array}{l}\text { DT } \\
\text { (EDI) }\end{array}$ & $\begin{array}{l}\text { B } \\
\text { (EDI) }\end{array}$ & $\begin{array}{l}\text { BD } \\
\text { (EDI) }\end{array}$ & $\begin{array}{l}\text { EDE- } \\
\text { Q }\end{array}$ & Control \\
\hline 1985 & $\begin{array}{l}\text { Szmukler et } \\
\text { al. }\end{array}$ & UK & 100 & $f$ & 15.6 & Ballet & Elite st & EAT-26 & 16 & 18.9 & $\mathrm{n} / \mathrm{a}$ & $\mathrm{n} / \mathrm{a}$ & $\mathrm{n} / \mathrm{a}$ & $\mathrm{n} / \mathrm{a}$ & $\mathrm{n} / \mathrm{a}$ & $\mathrm{n} / \mathrm{a}$ & No \\
\hline 1986 & Schnitt et al. & USA & 62 & $f$ & 22.6 & General & $\begin{array}{l}\text { Non elite } \\
\text { students }\end{array}$ & EAT-40 & 8 & 18 & $\mathrm{n} / \mathrm{a}$ & $\mathrm{n} / \mathrm{a}$ & $\mathrm{n} / \mathrm{a}$ & $\mathrm{n} / \mathrm{a}$ & $\mathrm{n} / \mathrm{a}$ & $\mathrm{n} / \mathrm{a}$ & No \\
\hline 1987 & $\begin{array}{l}\text { Brooks-Gunn } \\
\text { et al. }\end{array}$ & USA & 55 & $f$ & 24.7 & Ballet & Prof. & EAT-26 & $\mathrm{n} / \mathrm{a}$ & $\mathrm{n} / \mathrm{a}$ & 3.57 & $\mathrm{n} / \mathrm{a}$ & $\mathrm{n} / \mathrm{a}$ & $\mathrm{n} / \mathrm{a}$ & $\mathrm{n} / \mathrm{a}$ & $\mathrm{n} / \mathrm{a}$ & No \\
\hline 1987 & Evers & USA & 21 & $f$ & 21.4 & General & $\begin{array}{l}\text { Non elite } \\
\text { students }\end{array}$ & EAT-40 & 33 & 21.8 & $\mathrm{n} / \mathrm{a}$ & $\mathrm{n} / \mathrm{a}$ & $\mathrm{n} / \mathrm{a}$ & $\mathrm{n} / \mathrm{a}$ & $\mathrm{n} / \mathrm{a}$ & $\mathrm{n} / \mathrm{a}$ & Yes \\
\hline 1988 & $\begin{array}{l}\text { Hamilton et al. } \\
\text { (Chinese) }\end{array}$ & USA & 17 & $f$ & 24.6 & Ballet & Prof. & EAT-26 & $\mathrm{n} / \mathrm{a}$ & $\mathrm{n} / \mathrm{a}$ & 2.45 & $\mathrm{n} / \mathrm{a}$ & $\mathrm{n} / \mathrm{a}$ & $\mathrm{n} / \mathrm{a}$ & $\mathrm{n} / \mathrm{a}$ & $\mathrm{n} / \mathrm{a}$ & No \\
\hline 1988 & $\begin{array}{l}\text { Hamilton et al. } \\
\text { (American) }\end{array}$ & USA & 19 & $f$ & 22.3 & Ballet & Prof. & EAT-26 & $\mathrm{n} / \mathrm{a}$ & $\mathrm{n} / \mathrm{a}$ & 2.37 & $\mathrm{n} / \mathrm{a}$ & $\mathrm{n} / \mathrm{a}$ & $\mathrm{n} / \mathrm{a}$ & $\mathrm{n} / \mathrm{a}$ & $\mathrm{n} / \mathrm{a}$ & No \\
\hline 1989 & $\begin{array}{l}\text { Martin \& } \\
\text { Bellisle }\end{array}$ & France & 23 & $f$ & 18.3 & Ballet & Elite st & EAT-40 & $\mathrm{n} / \mathrm{a}$ & 51.2 & $\mathrm{n} / \mathrm{a}$ & $\mathrm{n} / \mathrm{a}$ & $\mathrm{n} / \mathrm{a}$ & $\mathrm{n} / \mathrm{a}$ & $\mathrm{n} / \mathrm{a}$ & $\mathrm{n} / \mathrm{a}$ & No \\
\hline 1994 & $\begin{array}{l}\text { Le Grange et } \\
\text { al. }\end{array}$ & S Africa & 49 & $f$ & 18.9 & Ballet & Elite st & EAT-40 & 16 & 17.9 & $\mathrm{n} / \mathrm{a}$ & $\mathrm{n} / \mathrm{a}$ & $\mathrm{n} / \mathrm{a}$ & $\mathrm{n} / \mathrm{a}$ & $\mathrm{n} / \mathrm{a}$ & $\mathrm{n} / \mathrm{a}$ & No \\
\hline 1994 & $\begin{array}{l}\text { Holderness et } \\
\text { al. }\end{array}$ & USA & 50 & $f$ & 20.9 & Ballet & Prof. & EAT-26 & 16 & $\mathrm{n} / \mathrm{a}$ & 13.55 & $\mathrm{n} / \mathrm{a}$ & $\mathrm{n} / \mathrm{a}$ & $\mathrm{n} / \mathrm{a}$ & $\mathrm{n} / \mathrm{a}$ & $\mathrm{n} / \mathrm{a}$ & Yes \\
\hline 1996 & $\begin{array}{l}\text { Fogelholm et } \\
\text { al. }\end{array}$ & $\begin{array}{l}\text { Netherlan } \\
\text { ds }\end{array}$ & 113 & $f$ & 23.3 & Ballet & Prof. & EDI I & $\mathrm{n} / \mathrm{a}$ & $\mathrm{n} / \mathrm{a}$ & $\mathrm{n} / \mathrm{a}$ & 25.8 & $\mathrm{n} / \mathrm{a}$ & $\mathrm{n} / \mathrm{a}$ & $\mathrm{n} / \mathrm{a}$ & $\mathrm{n} / \mathrm{a}$ & No \\
\hline 1998 & Bettle et al. & Germany & 32 & $\mathrm{~m}$ & 14.4 & Ballet & Elite st & EAT-40 & 0 & $\mathrm{n} / \mathrm{a}$ & $n / a$ & $\mathrm{n} / \mathrm{a}$ & $\mathrm{n} / \mathrm{a}$ & $\mathrm{n} / \mathrm{a}$ & $\mathrm{n} / \mathrm{a}$ & $\mathrm{n} / \mathrm{a}$ & No \\
\hline
\end{tabular}




\begin{tabular}{|c|c|c|c|c|c|c|c|c|c|c|c|c|c|c|c|c|c|}
\hline 1998 & Bettle et al. & Germany & 58 & $f$ & 14.4 & Ballet & Elite st & EAT-40 & 14 & $\mathrm{n} / \mathrm{a}$ & $\mathrm{n} / \mathrm{a}$ & $\mathrm{n} / \mathrm{a}$ & $\mathrm{n} / \mathrm{a}$ & $\mathrm{n} / \mathrm{a}$ & $\mathrm{n} / \mathrm{a}$ & $\mathrm{n} / \mathrm{a}$ & no \\
\hline 1999 & $\begin{array}{l}\text { Piran (primary } \\
\text { school) }\end{array}$ & Canada & 45 & $f$ & 13.3 & Ballet & Elite st & $\begin{array}{l}\text { EAT-26 } \\
\text { and EDI }\end{array}$ & 13 & $\mathrm{n} / \mathrm{a}$ & 9.2 & 17.1 & $\mathrm{n} / \mathrm{a}$ & $\mathrm{n} / \mathrm{a}$ & $\mathrm{n} / \mathrm{a}$ & $\mathrm{n} / \mathrm{a}$ & No \\
\hline 1999 & $\begin{array}{l}\text { Piran } \\
\text { (secondary } \\
\text { school) }\end{array}$ & Canada & 23 & $f$ & 13.4 & Ballet & Elite st & EAT-26 & 50 & $\mathrm{n} / \mathrm{a}$ & 17.3 & 21.9 & $\mathrm{n} / \mathrm{a}$ & $\mathrm{n} / \mathrm{a}$ & $\mathrm{n} / \mathrm{a}$ & $n / a$ & No \\
\hline 2002 & Kaufman et al. & USA & 21 & $f$ & 23.2 & Ballet & Prof. & EAT-26 & $\mathrm{n} / \mathrm{a}$ & $\mathrm{n} / \mathrm{a}$ & 22.9 & $\mathrm{n} / \mathrm{a}$ & $n / a$ & $n / a$ & $n / a$ & $\mathrm{n} / \mathrm{a}$ & Yes \\
\hline 2002 & $\begin{array}{l}\text { Dotti et al. } \\
\text { (children) }\end{array}$ & Italy & 75 & $f$ & 12.6 & General & $\begin{array}{l}\text { Non elite } \\
\text { students }\end{array}$ & $\begin{array}{l}\text { EAT-26, } \\
\text { EDI }\end{array}$ & $\mathrm{n} / \mathrm{a}$ & $\mathrm{n} / \mathrm{a}$ & 5.13 & $\mathrm{n} / \mathrm{a}$ & 1.8 & 0.16 & 3.56 & $\mathrm{n} / \mathrm{a}$ & No \\
\hline 2002 & $\begin{array}{l}\text { Dotti et al. } \\
\text { (adolescents) }\end{array}$ & Italy & 36 & $f$ & 16.1 & General & $\begin{array}{l}\text { Non elite } \\
\text { students }\end{array}$ & $\begin{array}{l}\text { EAT-26, } \\
\text { EDI }\end{array}$ & $\mathrm{n} / \mathrm{a}$ & $\mathrm{n} / \mathrm{a}$ & 10.92 & $\mathrm{n} / \mathrm{a}$ & 5.64 & 0.81 & 10.22 & $\mathrm{n} / \mathrm{a}$ & No \\
\hline 2002 & $\begin{array}{l}\text { Dotti et al. } \\
\text { (young adults) }\end{array}$ & Italy & 30 & $f$ & 20.5 & General & $\begin{array}{l}\text { Non elite } \\
\text { students }\end{array}$ & $\begin{array}{l}\text { EAT-26, } \\
\text { EDI }\end{array}$ & $\mathrm{n} / \mathrm{a}$ & $\mathrm{n} / \mathrm{a}$ & 9.33 & $\mathrm{n} / \mathrm{a}$ & 4.4 & 1.93 & 7.27 & $\mathrm{n} / \mathrm{a}$ & No \\
\hline 2002 & $\begin{array}{l}\text { Dotti et al. } \\
\text { (adults) }\end{array}$ & Italy & 19 & $f$ & 24.5 & General & $\begin{array}{l}\text { Non elite } \\
\text { students }\end{array}$ & $\begin{array}{l}\text { EAT-26, } \\
\text { EDI, }\end{array}$ & $\mathrm{n} / \mathrm{a}$ & $\mathrm{n} / \mathrm{a}$ & 11.21 & $\mathrm{n} / \mathrm{a}$ & 6.37 & 1.84 & 9.11 & $\mathrm{n} / \mathrm{a}$ & No \\
\hline 2003 & Ravaldi et al. & Italy & 113 & $f$ & 16.2 & Ballet & $\begin{array}{l}\text { Non elite } \\
\text { students }\end{array}$ & EDEQ & $\mathrm{n} / \mathrm{a}$ & $\mathrm{n} / \mathrm{a}$ & $\mathrm{n} / \mathrm{a}$ & $\mathrm{n} / \mathrm{a}$ & $\mathrm{n} / \mathrm{a}$ & $\mathrm{n} / \mathrm{a}$ & $\mathrm{n} / \mathrm{a}$ & 1.6 & No \\
\hline 2003 & Batur et al. & Turkey & 12 & $\mathrm{~m}$ & 23.0 & $\begin{array}{l}\text { Turkish } \\
\text { dance }\end{array}$ & Prof. & EAT-40 & $\mathrm{n} / \mathrm{a}$ & 18.2 & $\mathrm{n} / \mathrm{a}$ & $\mathrm{n} / \mathrm{a}$ & $\mathrm{n} / \mathrm{a}$ & $\mathrm{n} / \mathrm{a}$ & $\mathrm{n} / \mathrm{a}$ & $\mathrm{n} / \mathrm{a}$ & Yes \\
\hline 2003 & Batur et al. & Turkey & 12 & $\mathrm{~m}$ & 23.0 & $\begin{array}{l}\text { Turkish } \\
\text { dance }\end{array}$ & Amat. & EAT-40 & $\mathrm{n} / \mathrm{a}$ & 12.8 & $\mathrm{n} / \mathrm{a}$ & $\mathrm{n} / \mathrm{a}$ & $\mathrm{n} / \mathrm{a}$ & $\mathrm{n} / \mathrm{a}$ & $\mathrm{n} / \mathrm{a}$ & $\mathrm{n} / \mathrm{a}$ & Yes \\
\hline 2003 & Batur et al. & Turkey & 32 & $f$ & 22.1 & $\begin{array}{l}\text { Turkish } \\
\text { dance }\end{array}$ & Prof. & EAT-40 & $n / a$ & 34.9 & $\mathrm{n} / \mathrm{a}$ & $\mathrm{n} / \mathrm{a}$ & $\mathrm{n} / \mathrm{a}$ & $\mathrm{n} / \mathrm{a}$ & $\mathrm{n} / \mathrm{a}$ & $\mathrm{n} / \mathrm{a}$ & Yes \\
\hline 2003 & Batur et al. & Turkey & 22 & $f$ & 22.1 & $\begin{array}{l}\text { Turkish } \\
\text { dance }\end{array}$ & Amat & EAT-40 & $\mathrm{n} / \mathrm{a}$ & 30.1 & $\mathrm{n} / \mathrm{a}$ & $\mathrm{n} / \mathrm{a}$ & $\mathrm{n} / \mathrm{a}$ & $\mathrm{n} / \mathrm{a}$ & $\mathrm{n} / \mathrm{a}$ & $\mathrm{n} / \mathrm{a}$ & Yes \\
\hline 2004 & Anshel & Australia & 57 & $f$ & 17.3 & Ballet & Non elite & EDI II & $\mathrm{n} / \mathrm{a}$ & $\mathrm{n} / \mathrm{a}$ & $\mathrm{n} / \mathrm{a}$ & $\mathrm{n} / \mathrm{a}$ & 9.26 & 2.56 & 16.56 & $\mathrm{n} / \mathrm{a}$ & Yes \\
\hline
\end{tabular}




\begin{tabular}{|c|c|c|c|c|c|c|c|c|c|c|c|c|c|c|c|c|c|}
\hline & & & & & & & students & & & & & & $(3.75)$ & (1.51) & $(2.57)$ & & \\
\hline 2005 & $\begin{array}{l}\text { Thomas et al. } \\
\text { (National) }\end{array}$ & USA & 63 & $f$ & 15.0 & Ballet & Elite st. & EDI I & $\mathrm{n} / \mathrm{a}$ & $\mathrm{n} / \mathrm{a}$ & $\mathrm{n} / \mathrm{a}$ & 81.9 & 18.8 & 13.7 & $\mathrm{n} / \mathrm{a}$ & $\mathrm{n} / \mathrm{a}$ & No \\
\hline 2005 & $\begin{array}{l}\text { Thomas et al. } \\
\text { (Regional) }\end{array}$ & USA & 64 & $f$ & 15.0 & Ballet & Elite st. & EDI I & $\mathrm{n} / \mathrm{a}$ & $\mathrm{n} / \mathrm{a}$ & $\mathrm{n} / \mathrm{a}$ & 72.1 & 13.8 & 11.9 & $\mathrm{n} / \mathrm{a}$ & $\mathrm{n} / \mathrm{a}$ & No \\
\hline 2005 & $\begin{array}{l}\text { Thomas et al. } \\
\text { (Local) }\end{array}$ & USA & 107 & $f$ & 15.0 & Ballet & $\begin{array}{l}\text { Non elite } \\
\text { students }\end{array}$ & EDI I & $\mathrm{n} / \mathrm{a}$ & $\mathrm{n} / \mathrm{a}$ & $\mathrm{n} / \mathrm{a}$ & 78.5 & 16.3 & 13.0 & $\mathrm{n} / \mathrm{a}$ & $\mathrm{n} / \mathrm{a}$ & No \\
\hline 2006 & Ringham et al. & USA & 29 & $f$ & 19.7 & Ballet & Prof. & EDI I & $\mathrm{n} / \mathrm{a}$ & $\mathrm{n} / \mathrm{a}$ & $\mathrm{n} / \mathrm{a}$ & 43.4 & 11.27 & 2.32 & 12.14 & $\mathrm{n} / \mathrm{a}$ & No \\
\hline 2007 & Tseng et al. & Taiwan & 613 & $f$ & 15.8 & General & Elite st & EAT-26 & $\mathrm{n} / \mathrm{a}$ & $\mathrm{n} / \mathrm{a}$ & 17.2 & $\mathrm{n} / \mathrm{a}$ & $\mathrm{n} / \mathrm{a}$ & $\mathrm{n} / \mathrm{a}$ & $\mathrm{n} / \mathrm{a}$ & $\mathrm{n} / \mathrm{a}$ & Yes \\
\hline 2009 & Toro et al. & Spain & 76 & $f$ & 14.4 & $\begin{array}{l}\text { General } \\
\text { dance }\end{array}$ & $\begin{array}{l}\text { Non elite } \\
\text { students }\end{array}$ & EAT-26 & 11.8 & $\mathrm{n} / \mathrm{a}$ & $\mathrm{n} / \mathrm{a}$ & $\mathrm{n} / \mathrm{a}$ & $\mathrm{n} / \mathrm{a}$ & $\mathrm{n} / \mathrm{a}$ & $\mathrm{n} / \mathrm{a}$ & $\mathrm{n} / \mathrm{a}$ & No \\
\hline 2010 & $\begin{array}{l}\text { Ribeiro \& } \\
\text { Veiga }\end{array}$ & Brazil & 29 & $\mathrm{~m}$ & 38.0 & Ballet & Prof. & $\begin{array}{l}\text { EAT-26 + } \\
\text { BITE }\end{array}$ & 14 & $\mathrm{n} / \mathrm{a}$ & $\mathrm{n} / \mathrm{a}$ & $\mathrm{n} / \mathrm{a}$ & $\mathrm{n} / \mathrm{a}$ & $\mathrm{n} / \mathrm{a}$ & $\mathrm{n} / \mathrm{a}$ & $\mathrm{n} / \mathrm{a}$ & No \\
\hline 2010 & $\begin{array}{l}\text { Ribeiro \& } \\
\text { Veiga }\end{array}$ & Brazil & 50 & $f$ & 36.8 & Ballet & Prof. & $\begin{array}{l}\text { EAT-26 + } \\
\text { BITE }\end{array}$ & 10 & $\mathrm{n} / \mathrm{a}$ & $\mathrm{n} / \mathrm{a}$ & $\mathrm{n} / \mathrm{a}$ & $\mathrm{n} / \mathrm{a}$ & $\mathrm{n} / \mathrm{a}$ & $\mathrm{n} / \mathrm{a}$ & $\mathrm{n} / \mathrm{a}$ & No \\
\hline 2011 & Herbrich et al. & Germany & 52 & $f$ & 16.4 & Ballet & $\begin{array}{l}\text { Elite } \\
\text { students }\end{array}$ & EDI I & $\mathrm{n} / \mathrm{a}$ & $\mathrm{n} / \mathrm{a}$ & $\mathrm{n} / \mathrm{a}$ & $\mathrm{n} / \mathrm{a}$ & 20.58 & 14.06 & 29.63 & $\mathrm{n} / \mathrm{a}$ & Yes \\
\hline 2011 & $\begin{array}{l}\text { Nordin-Bates } \\
\text { et al. }\end{array}$ & UK & 85 & $\mathrm{~m}$ & & General & Elite st & EAT-26 & 8 & $\mathrm{n} / \mathrm{a}$ & $\mathrm{n} / \mathrm{a}$ & $\mathrm{n} / \mathrm{a}$ & $\mathrm{n} / \mathrm{a}$ & $\mathrm{n} / \mathrm{a}$ & $\mathrm{n} / \mathrm{a}$ & $\mathrm{n} / \mathrm{a}$ & No \\
\hline 2011 & $\begin{array}{l}\text { Nordin-Bates } \\
\text { et al. }\end{array}$ & UK & 261 & $f$ & 14.4 & General & Elite st & EAT-26 & 7 & $\mathrm{n} / \mathrm{a}$ & $\mathrm{n} / \mathrm{a}$ & $\mathrm{n} / \mathrm{a}$ & $\mathrm{n} / \mathrm{a}$ & $\mathrm{n} / \mathrm{a}$ & $\mathrm{n} / \mathrm{a}$ & $\mathrm{n} / \mathrm{a}$ & No \\
\hline 2011 & $\begin{array}{l}\text { Burckhardt et } \\
\text { al. }\end{array}$ & Switz. & 127 & $f$ & 16.7 & General & Prof. & EAT-40 & $\mathrm{n} / \mathrm{a}$ & 12.6 & $\mathrm{n} / \mathrm{a}$ & $\mathrm{n} / \mathrm{a}$ & $\mathrm{n} / \mathrm{a}$ & $\mathrm{n} / \mathrm{a}$ & $\mathrm{n} / \mathrm{a}$ & $\mathrm{n} / \mathrm{a}$ & No \\
\hline 2012 & $\begin{array}{l}\text { Penniment \& } \\
\text { Egan }\end{array}$ & Australia & 142 & $f$ & 22.3 & General & Non-prof & EDEQ & $\mathrm{n} / \mathrm{a}$ & $\mathrm{n} / \mathrm{a}$ & $\mathrm{n} / \mathrm{a}$ & $\mathrm{n} / \mathrm{a}$ & $\mathrm{n} / \mathrm{a}$ & $\mathrm{n} / \mathrm{a}$ & $\mathrm{n} / \mathrm{a}$ & 1.85 & No \\
\hline 2012 & Francisco et & Portugal & 13 & $m$ & 15.0 & Ballet & Elite st. & EDE-Q & $\mathrm{n} / \mathrm{a}$ & $\mathrm{n} / \mathrm{a}$ & $\mathrm{n} / \mathrm{a}$ & $\mathrm{n} / \mathrm{a}$ & $\mathrm{n} / \mathrm{a}$ & $\mathrm{n} / \mathrm{a}$ & $\mathrm{n} / \mathrm{a}$ & 0.46 & Yes \\
\hline
\end{tabular}




\begin{tabular}{|c|c|c|c|c|c|c|c|c|c|c|c|c|c|c|c|c|c|}
\hline & al. & & & & & & & & & & & & & & & & \\
\hline 2012 & $\begin{array}{l}\text { Francisco et } \\
\text { al. }\end{array}$ & Portugal & 53 & $f$ & 14.6 & Ballet & Elite st. & EDE-Q & $\mathrm{n} / \mathrm{a}$ & $\mathrm{n} / \mathrm{a}$ & $\mathrm{n} / \mathrm{a}$ & $\mathrm{n} / \mathrm{a}$ & $\mathrm{n} / \mathrm{a}$ & $\mathrm{n} / \mathrm{a}$ & $\mathrm{n} / \mathrm{a}$ & 1.54 & Yes \\
\hline 2012 & $\begin{array}{l}\text { Francisco et } \\
\text { al. }\end{array}$ & Portugal & 47 & $f$ & 14.6 & Ballet & $\begin{array}{l}\text { Non elite } \\
\text { students }\end{array}$ & EDE-Q & $n / a$ & $\mathrm{n} / \mathrm{a}$ & $\mathrm{n} / \mathrm{a}$ & $\mathrm{n} / \mathrm{a}$ & $\mathrm{n} / \mathrm{a}$ & $\mathrm{n} / \mathrm{a}$ & $\mathrm{n} / \mathrm{a}$ & 0.69 & Yes \\
\hline 2012 & $\begin{array}{l}\text { Van Durme et } \\
\text { al. }\end{array}$ & Belgium & 44 & $f$ & 14.5 & Ballet & Elite st. & EDI-II & $\mathrm{n} / \mathrm{a}$ & $n / a$ & $n / a$ & $n / a$ & 20.8 & 13.46 & 29.54 & $\mathrm{n} / \mathrm{a}$ & Yes \\
\hline
\end{tabular}

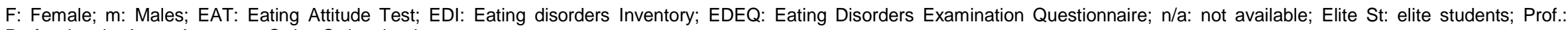
Professionals; Amat: Amateurs ;Switz: Switzerland 